\title{
AKTUALISASI SYARIAH DAN FIKIH DALAM MENYELESAIKAN PELBAGAI PERSOALAN HUKUM
}

\author{
Abdul Wahab Abd. Muhaimin \\ Fakultas Syariah dan Hukum UIN Syarif Hidayatullah Jakarta \\ Jl. Ir. H. Juanda No. 95, Ciputat Timur, Tangerang Selatan \\ E-mail: abdul.wahab@uinjkt.ac.id
}

\begin{abstract}
The Actualization of Sharia and Fiqh in Resolving Various Legal Issues. In line with the dynamics of society and the advancement of science, various contemporary legal issues occur. This issues need solution from Islamic law. This study indicated that Islam law still based on Al-Qur'an and Hadith and it still relevan tgroughout the ages, and it will always correspond to the society and technology. It convenients with the rule: "Islam is appropriate and relevant to every condition, state, time, and place".
\end{abstract}

Keyword: islamic law, fiqh, islamic actualizastion, islamic kontemporer law

\begin{abstract}
Abstrak. Aktualisasi Syariab dan Fikih dalam Menyelesaikan Berbagai Persoalan Hukum. Sejalan dengan dinamika masyarakat dan kemajuan ilmu pengetahuan, pelbagai masalah hukum kontemporer muncul ke permukaan. Permasalahanpermasalahan hukum terkait ini memerlukan jawaban dari hukum Islam. Studi ini menunjukkan bahwa ajaran Islam yang berpegang kepada Alquran dan Hadis sebagai sumber syariah dan fikih tetap relevan sepanjang zaman, dan akan selalu seiring dengan perkembangan masyarakat dan kemajuan IPTEK. Hal ini sesuai dengan kaidah, "Islam sesuai dan relevan dengan setiap kondisi, keadaan, waktu, dan tempat".
\end{abstract}

Kata kunci: syariah, fikih, aktualisasi syariah, hukum Islam kontemporer

\section{Pendahuluan}

Seiring dengan perkembangan zaman, masyarakat dan kemajuan ilmu pengetahuan serta teknologi, berbagai masalah hukum muncul ke permukaan di tengah-tengah masyarakat dewasa ini, yang tempo doeloe tidak ada, atau sudah ada tetapi belum berevolusi, kini bermunculan bak jamur di musim hujan, yang selanjutnya menuntut jawaban dari segi hukum, yaitu syariah dan fikih di mana pada saat ini sebagian Muslim itu sendiri telah beranggapan, bahwa syariat Islam yang bersumber dari Alquran dan Sunah Rasulullah Saw, sebagiannya sudah tidak relevan lagi dengan kondisi sekarang ini dan banyak permasalahan yang aktual bermunculan, belum diayomi oleh Alquran dan Sunnah Rasul tersebut. Sebenarnya semua masalah aktual dapat diselesaikan dan ditetapkan hukumnya dengan syariat Islam, yaitu dengan Alquran dan Sunnah Rasulullah, atau dengan fikih, karena fikih itu sendiri

Naskah diterima: 2 Februari 2015, direvisi: 4 April 2015, disetujui untuk terbit: 20 Juni 2015.

*Pidato Pengukuhan Guru Besar pada hari Sabtu, Tanggal 21 Februari 2015 di Auditorium Prof. DR. Harun Nasution, UIN Syarif Hidayatullah Jakarta. adalah penampakan pemahaman dan interpretasi dari nash-nash Alquran dan Sunah melalui ijtihad. Berikut ini akan dibahas beberapa permasalahan, atau kasus aktual yang dapat ditetapkan dan diselesaikan hukumnya berdasarkan syariat dan fikih, yang keduanya ini populer disebut dengan Hukum Islam.

\section{Terminologi Syariah}

Syariah menurut etimologi berarti sumber air yang dituju (didatangi) untuk minum. Kemudian kata syariah itu digunakan oleh orang-orang Arab dalam arti jalan yang lurus. ${ }^{1}$ Perubahan arti dari maknanya yang asli yakni "sumber air" menjadi jalan yang lurus, karena sumber air "mata air" merupakan sarana untuk hidup manusia, hewan dan tumbuh-tumbuhan yang menempati dunia ini selalu memerlukan air. Sebagaimana disebutkan Q.s. al-Anbiyầ, 30.

Adapun pengertian syariah menurut terminologi, antara lain seperti disebutkan oleh Mannâ' Khalil alQaththân ialah segala yang ditetapkan oleh Allah untuk para hamba-Nya, baik mengenai akidah, akhlak,

${ }^{1}$ Ibnu Manzhûr, Lisân al-'Arab (t.t.:Dar al-Maârif, t.th.), jilid III, h.2238-2239. 
muamalat, maupun tatanan kehidupan lainnya, dengan segala cabangnya yang bermacam-macam, guna merealisasikan kebahagiaan mereka, baik di dunia, maupun di akhirat. ${ }^{2}$ Menurut Muhammad Ali al-Thahanâwî, syariah ialah hukum-hukum yang ditetapkan oleh Allah untuk hamba-hambanya, yang dibawa oleh Nabi-Nya, baik itu sebagai hukum furu (cabang) dan al-'amaliyah (perbuatan) dan untuknya dihimpunlah "ilmu fiqh", atau berhubungan dengan cara menentukan kepercayaan (itiqâd) yang disebut hukum pokok dan kepercayaan, yang untuknya dihimpunlah "ilmu kalam". Syara' (syariah) disebut juga dengan al-Din dan al-Millah (agama). ${ }^{3}$

Dari definisi-definisi tersebut dapat dilihat, bahwa terminologi syariah dipakai dalam dua pengertian, yaitu dalam arti luas dan arti sempit. Dalam arti luas, syariah dimaksudkan adalah keseluruhan norma agama Islam, yang meliputi seluruh aspek, baik aspek doktrinal, maupun aspek praktis. Dalam arti sempit, syariah merujuk kepada aspek praktis dari ajaran Islam, yaitu bagian yang terdiri dari norma-norma yang mengatur tingkah laku konkrit manusia, seperti ibadah, nikah, berjual-beli, berperkara di pengadilan, menyelenggarakan Negara dan seterusnya. Apabila istilah "hukum Islam" hendak digunakan untuk menterjemahkan istilah "syariah" maka yang dimaksud adalah syariah dalam arti sempit. ${ }^{4}$

\section{Terminologi Fikih}

Dalam bahasa Arab fikih disebut figh dalam bentuk mashdar yang berarti pengetahuan dan pemahaman. ${ }^{5}$ Sedangkan pengertian fikih menurut Muhammad Abu Zahrah dan Abdul Wahhâb Khallâf ialah ilmu yang menerangkan hukum syara' yang 'amalî (praktis) yang diambil dari dalil-dalilnya yang terinci. ${ }^{6}$

Permasalahan Konflik Sosial

Konflik sosial adalah sesuatu yang lazim dalam kehidupan, namun konflik itu tidak boleh dibiarkan berlarut-larut, karena akan menimbulkan kesenjangan dan kesengsaraan bagi masyarakat. Berbagai konflik

\footnotetext{
${ }^{2}$ Mannầ Khalîl al-Qaththân, al-Tashrì' wa al-fiqh fi al-Islàm: Târîkhan wa Manhajan (t.t.: Maktabah Wahbah, 1976), h.10.

${ }^{3}$ Muhammad al-Thahanâwi, Kashshâf Ishthilâhâat al-Funûn (t.t.: alIstianah, $1317 \mathrm{H})$, Jilid I, h.835, 836.

${ }^{4}$ Abdul Wahab Abd. Muhaimin, Hukum Islam dan Kedudukan Perempuan dalam Perkawinan dan Perceraian (Jakarta: Gaung Persada Press, 2013) cet.I, ha. 5.

${ }^{5}$ Lihat: Ali Muhammad al-Jurjânî, al-Tárîfât (Mesir: MushThafâ alBâbî al-브alabî wa Aulâduh, 1938), h.147.

${ }^{6}$ Muhammad Abu Zahrah, Ushûl al-Fiqh (t.t.: Dar al-Fikr al-Arabî, t.th.) dan dari Abdul Wahhâb Khallâf, Ilmu ushûl fiqh (Kuwait: Dar alQalam: t.th).
}

sosial terjadi karena beberapa faktor antara lain; yaitu konflik karena saling mengejek antara satu dengan yang lainnya yang dilarang dalam syariat Islam, sebagaimana disebutkan dalam Al-Qur'an surah Al- $\underline{\text { Hujurât}}, 11$.

Ayat ini menjelaskan agar tidak saling merendahkan (menghina), tidak saling mencela dan tidak boleh memanggil dengan gelar yang mengandung ejekan. Konflik juga dapat terjadi karena berburuk sangka, atau karena perselisihan dan perbedaan orientasi serta kepentingan antara umat manusia, saling mengejek antar umat beragama karena tergiur oleh kehidupan dunia yang sarat fatamorgana sebagaimana diisyaratkan dalam Q.S. al-Baqarah: 212-213.

Konflik sosial di negeri yang tercinta Indonesia ini, antara lain seperti yang telah terjadi di Ambon dan Poso antara pemeluk agama Islam dan Katolik yang menelan korban ratusan bahkan ribuan jiwa serta menimbulkan kerugian moril dan materiil. Konflik terjadi di Sampit Kalimantan Tengah antara etnis Dayak dan etnis Madura pada Februari 2001, yang dipicu oleh perbedaan budaya. Konflik sosial terjadi antara warga satu kampung dengan kampung yang lain, antara para demonstran dengan aparat keamanan, antara suporter klub sepakbola, antara pendukung satu partai politik dengan yang lain, antara satu calon anggota legislatif dengan calon yang lain, tawuran antara satu kelompok pelajar di satu sekolah dengan kelompok pelajar di sekolah yang lain, antara pendukung calon bupati/ walikota, atau calon gubernur yang satu dengan calon yang lain, dan banyak lagi.

Berkenaan dengan pencegahan konflik sosial seperti yang telah disebutkan, Al-Qur'an dan Hadis sebagai sumber syariah dan fikih memerintahkan orang-orang mukmin, agar mengingatkan pihak-pihak yang bertikai, berantam, tawuran, bahkan ada yang saling membunuh, hendaklah mendamaikan mereka agar mendapat riđâ dari Allah Swt. Terlaksananya persaudaraan mukmin itu merupakan idaman umat Islam yang terbesar. Sebelum cita-cita itu terlaksana, ajaran Islam tidak akan dapat diwujudkan sepenuhnya. ${ }^{7}$ Allah Swt telah berpesan dalam Q.S. al- $\underline{\text { Hujurât: }} 10$.

Rasulullah telah meresolusi konflik sosial ketika beliau mendamaikan konflik yang tidak berkesudahan antara kabilah Aus dan Khazraj di Yatsrib (Madinah) atas provokasi kaum Yahudi. Demikian pula Rasulullah Saw telah mampersaudarakan kaum Muhajirin dan Anshar, yang telah diabadikan dalam Q.S. al- $\underline{H}$ ashr: 9.

Para pemimpin, tokoh-tokoh masyarakat dan ulama

${ }^{7}$ Abdullah Yusuf Ali, Qur'an Terjemahan dan Tafirnya, Terjemahan Ali Âudah (Jakarta: Pustaka Firdaus, 1993), h.250-251 
wajib menjaga perdamaian antara umat manusia dan umat beragama, dan hendaklah mencontoh cara-cara Rasulullah dalam mendamaikan yang bertikai dengan melakukan pendekatan ajaran syariat Islam, ${ }^{8}$ agar tidak terjadi permusuhan dan pertikaian yang berkepanjangan yang meresahkan masyarakat.

\section{Permasalahan Kerusakan Lingkungan}

Manusia dalam memenuhi kebutuhan hidup dan kehidupannya dari lingkungan. Semakin hari kebutuhan hidup manusia makin komplex dan beraneka ragam, sehingga makin besar pula jumlah kebutuhan hidup yang diambil dari lingkungan. Namun masih ada saja manusia yang tidak peduli dengan kelestarian lingkungannya, di mana kehidupan itu sendiri banyak menggunakan sumber hidup dari alam, namun tidak memperbaikinya. Keserakahan manusia menyebabkan kualitas lingkungan menjadi rendah. Contohnya, limbah industri, pencemaran air, pencemaran udara, penggundulan hutan, pengerukan batu-batu gunung, penambangan pasir di pantai yang berakibat abrasi, yang lebih jauh silih berganti datangnya berbagai bencana alam, sebagaimana disebutkan dalam firman Allah QS. al-Rūm: 41.

Menurut Fakhruddîn al-Râzî, terkait dengan kerusakan di darat dan di laut yang disebutkan pada ayat tersebut, terdapat beberapa pendapat ulama, antara lain; banjir besar (banjir bandang), musim paceklik dan kekurangan air. ${ }^{9}$ menurut Ibnu 'Âshūr kematian sia-sia, kebakaran, tenggelam, kezaliman dan prilaku-prilaku sesat, ${ }^{10}$ dan menurut al-Zamakhsharī adalah gagal panen dan krisis ekonomi. ${ }^{11}$

Secara umum, terjadinya degradasi lingkungan hidup ada dua penyebab, yaitu penyebab yang bersifat langsung dan tidak langsung.

Faktor penyebab yang tidak langsung pada kenyataannya merupakan penyebab yang sangat dominan terhadap kerusakan lingkungan. Artinya rusaknya ekosistem, dalam hal ini manusia, tidak memiliki peran, misalnya gunung meletus, gempa bumi, tsunami dan lain-lain.

Sedangkan yang bersifat langsung masuk pada ranah

\footnotetext{
${ }^{8}$ Kementrian Agama RI, "Al-Qur'an dan Isu-isu Kontemporer I", dalam Tafsir Al-Qur'an Tematik (Jakarta: Lajnah Pentashîh $\underline{h}$ Mush $\underline{h} a f$ AlQur'an, 2012), cet. I, h.22.

${ }^{9}$ Al-Râzī, Mafâtīin al-Ghaib (t.t. : Maktabah Shâmilah, t.th.), jilid XII, h. 245 .

${ }^{10}$ Ibnu Ăsyûr, Anwâr al-Tanzîl wa Atharu al-Tảwîl (t.t.: Maktabah Shâmilah, t.th.), jilid IV, h.486.

${ }^{11}$ Al-Zamakhsharî, al-Kashshâff(t.t. : Maktabah Shâmilah, t.th.), jilid V, h.259.
}

ulah manusia yaitu mengeksploitasi lingkungan secara berlebihan/besar-besaran karena desakan kebutuhan, keserakahan, atau mungkin kekurangsadaran akan pentingnya menjaga lingkungan, misalnya menebang hutan yang berlebihan dan tidak beraturan illegal loging, membuang sampah sembarangan, menyebabkan penyempitan aliran sungai dan pendangkalan sehingga mengakibatkan banjir dan lain-lain. Bukan alam yang tidak bersahabat dengan manusia, tapi manusia itu sendiri yang tidak bersahabat dengan alam alias merusak lingkungan. Hal ini diisyaratkan dalam Q.S. al-Shūrâ: 30 dan Q.S. al-Rūm: 41.

Berdasarkan kedua ayat tersebut, jelas disebutkan bahwa bencana alam terjadi dan kerusakan lingkungan adalah akibat ulah manusia. Padahal Allah Swt melarang membuat kerusakan di muka bumi dalam firman-Nya Q.S. al-A'râf: 56.

Larangan Allah agar tidak berbuat kerusakan di muka bumi ini adalah menunjukkan hukumnya haram, pada dasarnya hukum larangan (النهي) adalah haram:

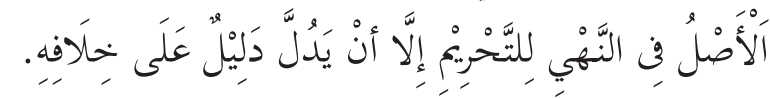

Pada dasarnya larangan itu menunjukkan haram, kecuali ada dalil atau indikasi lain, yang menetapkan sebaliknya.

Dengan demikian, merusak lingkungan haram hukumnya. Oleh karena itu, pendidikan berbasis lingkungan saat ini, sudah sangat mendesak untuk diajarkan pada anak-anak didik dan generasi muda. Dengan demikian, sejak dini, mereka telah memiliki pengetahuan yang memadai tentang lingkungan hidup yang asri dan lestari untuk kehidupan semua makhluk, khususnya manusia generasi sekarang dan yang akan datang. Di Universitas al-Azhar Kairo Mesir telah dimasukkan dalam kurikulum dan silabusnya mata kuliah fikih lingkungan (فقه البيئة).

Menurut Undang-Undang No. 23 tahun 1997, pelestarian lingkungan hidup adalah rangkaian upaya untuk melindungi kemampuan dan ketahanan lingkungan hidup itu sendiri terhadap tekanan perubahan atau dampak negatif, yang ditimbulkan oleh suatu kegiatan, agar mampu mendukung perikehidupan manusia dan ekosistem lainnya.

Di antara usaha menjaga lingkungan adalah dengan sanitasi lingkungan. Sanitasi lingkungan adalah menciptakan lingkungan yang sehat dan bebas dari penyakit. Penyakit usus yang berbahaya seperti tipes, diare, muntaber, dan kolera dapat dikurangi dan dicegah dengan membiasakan menjaga kebersihan diri dan lingkungan. Kebersihan adalah pangkal kesehatan. Kebersihan itu adalah sebagian dari iman (النظافة من الإِعان) 


\section{Permasalahan Korupsi}

Korupsi adalah tindakan atau perbuatan memanfaatkan jabatan dan kedudukan untuk mendapatkan keuntungan, baik material, atau prestise bagi pribadi, keluarga, atau kelompok, tanpa melihat kapabilitas, profesionalitas dan moralitas, dengan cara dan jalan melanggar ketentuan-ketentuan hukum yang ada, yang akibatnya merugikan orang lain, masyarakat, bangsa dan Negara. ${ }^{12}$

Korupsi termasuk tindak kejahatan, sama dengan illegal logging, illegal fishing, penyelundupan barang, perdagangan manusia dan NARKOBA, perjudian dan kejahatan perpajakan, biasanya menghasilkan uang dalam jumlah yang raksasa. Agar tidak muda dilacak asal-usulnya, para pelaku tidak langsung menggunakan dana tersebut, akan tetapi melakukan upaya parkir dana/ penyembunyian dengan memasukkan ke dalam sistem keuangan dan perbankan sehingga nampak legal. Inilah yang dikenal dengan istilah pencucian uang, atau money laundring. ${ }^{13}$

Dengan kemajuan teknologi, tindak kejahatan ini bukan hanya menjadi masalah nasional, tapi juga internasional, mengingat sang pelaku bisa melakukan pemindahan uang dari satu negara ke negara lain. Dengan dukungan teknologi, kejahatan ini menjadi sulit dilacak (untraceable crime) karena tidak ada bukti tertulis (paperless crime), dan tidak kasat mata (dicernible crime). Selain itu dilakukan dengan cara yang rapih dan rumit. ${ }^{14}$ Larangan melakukan korupsi dan penipuan, memakan dan mengambil harta orang lain dengan cara yang batil, disebutkan dalam Q.S. al-Baqarah: 188. Dalam ayat lain Allah berfirman dalam surah Ali 'Imrân: 161.

Dari ayat pertama dan kedua yang telah disebutkan, terdapat diktum tudlû (تدلوا), al-bâthil (الباطل) dan yaghlul (يغل).

Kata tudlû dalam bahasa Arab berarti mengulurkan ember ke dalam sumur untuk memperoleh air. ${ }^{15}$ Maksudnya dalam ayat tersebut adalah memberi sogokan kepada Hakim agar menjatuhkan putusan yang menguntungkannya, sehingga milik orang lain menjadi miliknya. Hukum tumpul ke atas dan tajam ke bawah

${ }^{12}$ Kementrian Agama RI, "Pembangunan Ekonomi Umat Islam", dalam Tafsir Al-Qur'an Tematik, h.114.

13 Kementrian Agama RI, "Al-Qur'an dan Isu-isu Kontemporer I", dalam Tafsir Al-Qur'an Tematik, h.336

${ }^{14}$ Adrian Sutedi, Tindak Pidana Pencucian Uang (Bandung: Citra Aditya Bakti, 2008), 233. Lihat pula: Jaes D. Harmon Jr, "Money Laoundring Legislation: Hearing of the Senat Comm", On The Judiciary, 99th Cong, Vol. 84, 1985, h.2.

${ }^{15}$ Majma' al-Lughah al-'Arabiyah, al-Mu'jam al-WasîTh (Mesir: Dar al-Ma'ârif 1392 H/1972 M), Jilid I, h.295. merupakan model layaknya sinetron yang ditayangkan di sementara panggung pengadilan di Negri ini yang natijahnya berakibat adanya pendekar-pendekar hukum masuk ke dalam bui/penjara, baik itu kelas kakap atau kelas teri. Penggunaan kata tudlûini mengisyaratkan rendahnya martabat Hakim yang mau menerima sogokan, seakan ia berada di dasar sumur menanti uluran dari atas. ${ }^{16}$ Sedangkan kata al-bâțil menurut bahasa Arab berarti, yang hilang, yang batil, yang rusak, atau yang rugi. ${ }^{17}$ Dengan demikian, al- bâţ̦ilyang dimaksudkan oleh ayat 188 al-Baqarah tersebut, adalah suatu perbuatan, atau cara yang dilakukan oleh seseorang, yang tidak mengikut aturan, atau hukum yang telah ditentukan oleh syariat Islam, seperti melakukan korupsi, suap, pencucian uang dan lain-lain, baik untuk kepentingan perorangan dan keluarga, maupun untuk kepentingan kelompok, yang dapat menghilangkan hak orang lain, atau dapat mendatangkan kerugian bagi masyarakat, atau Negara. Demikian pula kata yaghlul berarti curang atau mengambil sesuatu dengan cara sembunyi-sembunyi, dimaksudkan dalam ayat 161 Âli 'Imrân tersebut, adalah pengkhianatan dengan cara mengambil harta rampasan perang, atau harta orang lain.

Menurut para mufassirîn, antara lain al-Qurţubī, bahwa ayat 188 al-Baqarah itu menerangkan, bahwa Allah melarang untuk memakan harta orang lain dengan jalan yang batil, seperti larangan makan hasil judi, tipuan, rampasan dan paksaan untuk mengambil hak orang lain yang tidak atas kerelaan pemiliknya, atau yang diharamkan oleh syariat Islam meskipun atas kerelaan pemiliknya. Termasuk dalam kategori memakan yang batil adalah rishwah (Grarifikasi) kepada hakim. ${ }^{18}$ Melakukan korupsi haram hukumnya, karena dalam ayat tersebut menggunakan لاناهية dalam ushîl figh menunjukkan haram. Apalagi Nabi Muhammad Saw telah menegaskan dalam Hadisnya:

$$
\begin{aligned}
& \text { كل جسد نبت من سحت فالنار أولي به رواه أحمد }
\end{aligned}
$$

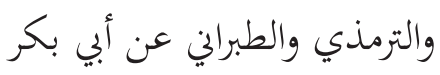

Setiap jasad yang tumbuh dari sesuatu yang haram, maka api neraka lebih layak baginya (HR. Ahmad, alTirmidzî dari Abi Bakar).

${ }^{16}$ Depag RI, Al-Qu'an dan Tafsirnya (edisi yang disempurnakan) (Jakarta: Balitbang Agama, 1425 H/2004 M), cet. I, h.238 h.61.

${ }^{17}$ Majma' al-Lughah al-'Arabiyah, al-Mújam al-WashîTh, Jilid I,

${ }^{18}$ Al-Qurţubī, al-Jâmi' li Alhkâm Al-Qur'an(t.t. : t. p., 1372 H/1952 M), Jilid II 338. Dalam Hadis Nabi Muhammad Saw dikatakan :

》 لعن الله الراشي والمرتشي في الحكم 》 رواه أحمد و الترمذي والحاكم عن أبي هريرها.

"Allah mengutuk orang yang menyogok dan orang yang disogok dalam memutuskan perkara". (HR. al-Tirmīzī dan al-Hâakim dari Abi Hurairah) 
Dalam diktum Hadis lain disebutkan:

$$
\text { كل لحم نبت من حرام فالنار أولي به }
$$

"setiap daging yang tumbuh dari sesuatu yang haram maka Neraka lebih pantas baginya"

Segala sesuatu yang diancam dengan siksaan api neraka menurut Ulama ushûl fikih adalah haram hukumnya. Banyak ayat-ayat Al-Qur'an dan Hadis yang menyatakan haram hukumnya memakan harta orang lain dengan jalan yang batil, termasuk dalam hal ini adalah korupsi dan suap. Hanya saja sanksi/hukuman bagi pelaku korupsi (غلول) belum ditentukan dalam AlQur'an dan Hadis. Oleh sebab itu, hukuman bagi pelaku korupsi menurut fiqh jinâyât (hukum pidana Islam) adalah $t a^{\prime} z i r$ yaitu hukuman yang dikenakan kepada pelaku tindak pidana diserahkan kepada kebijaksanaan Hakim untuk menentukan berat dan ringannya, bahkan bisa sampai kepada hukuman mati seperti di Cina juga sebagaimana disebutkan oleh 'Abdul 'Azīz Amīr dalam kitabnya "al-Ta’zìr fi al-Sharî́ah al-Islâmiyah", Abdul Muhsin al-Turkī dalam kitabnya "Jarimah al-Rishwah fi al-Sharî‘ah al-Islâmiyah", Wahbah al-Zuhailî dalam kitabnya "al-Fiqh al-Islâmî wa 'Adillatuhu" dan 'Abdul Qâdir 'Audah dalam kitabnya "al-Tashrî̀ al-Jinầî alIslâmî̀ ". ${ }^{19}$ Menurut mereka, hukuman mati dapat dikenakan kepada koruptor, tergantung tindak pidana korupsi yang dilakukan.

$$
\text { تصرف الإمام على الرعية منوط بالمصلحة20 }
$$

Tindakan Imam (pemegang otoritas) terhadap rakyat harus mengikuti maslahat.

Dengan ini dapat disimpulkan, bahwa hukuman bagi pelaku korupsi, adalah $t a^{\prime} z i r$, bisa ringan dan bisa berat, tergantung tindak pidana korupsi yang dilakukan, bahkan bisa dikenakan hukuman mati seperti yang tercantum dalam UU. No: 31, Tahun 1999, pasal 2 ayat (2), bahwa korupsi yang dilakukan dalam keadaan tertentu, dapat dijatuhkan hukuman mati. Di samping itu, semua harta hasil korupsi harus dikembalikan ke Negara, hal ini sesuai dengan prinsip syariah dan fiqh jinâyat.

\section{Permasalahan Miras dan Narkoba}

Larangan mengkonsumsi MIRAS dijelaskan secara tegas dalam Al-Qur'an dan Hadis. MIRAS diharamkan secara bertahap, yaitu 4 tahap dalam waktu yang berbeda, disesuaikan dengan kondisi masyarakat Arab

${ }^{19}$ Lihat: Kementrian Agama RI, "Pembangunan Ekonomi Umat" dalam "Tafir Al-Qur'an Tematik", h.139-140.

${ }^{20}$ Jalâluddîn al-Suyûthî, al-Ashbâh wa al-Nazhẩir, (Bairut: Dar alFikr, 1415H/1995M), Jilid I, h.84 ketika diturunkan Al-Qur'an.Tahap Pertama, disebutkan pada Q.S al-Nahli: 67.

Allah menjelaskan, bahwa khamr (minuman yang memabukkan) adalah berbahan baku dari kurma dan anggur, Pada saat itu, minuman ini merupakan salah satu sumber rezeki masyarakat Arab, seakanakan ayat ini mengisyaratkan bahwa minuman yang memabukkan (MIRAS) bukan termasuk rezeki yang baik, ${ }^{21}$ sehingga masyarakat Arab bersikap hati-hati, namun belum sampai kepada menghindari konsumsi minuman tersebut. ${ }^{22}$

Tahap Kedua, disebutkan dalam Q.S al-Baqarah: 219. Dalam ayat tersebut Allah Swt. menjelaskana bahwa bahaya minuman keras (khamr) dan judi lebih besar dosa melaksanakannya daripada manfaatnya. Tetapi dalam ayat ini belum tegas melarang, karena masih menyebutkan bahwa adanya manfaat yang dapat diambil dari khamr. Sikap setelah turunnya ayat ini, sebagian dari kaum muslim mulai meninggalkan meminum khamr dan sebagian lainnya masih konsisten meminumnya. ${ }^{23}$

Tahap ketiga, disebutkan dalam Q.S al-Nisầ :43. Pada ayat ini Allah menggunakan lâ nâhiyah, suatu bentuk larangan yang pada dasarnya menurut ulama ushül adalah menunjukkan hukum haram. Akan tetapi, larangan tersebut belum tegas menunjuk langsung pada khamr, sehingga seandainya tidak memperhatikan sabab nuzūl ayat, tentu akan sulit menentukan bahwa ayat tersebut diturunkan dalam rangka pengharaman minuman keras (khamr). ${ }^{24}$ Dampak dari ayat ini umat Islam saat itu, tidak lagi mengkonsumsi minuman keras (khamr) kecuali setelah melakukan shalat Isya'. ${ }^{25}$ Sebab larangan mabuk dari ayat tersebut, hanya terbatas pada larangan shalat ketika mabuk, dalam arti dilarang konsumsi khamr sebelum shalat.

Tahap Keempat, surah al-Mâidah ayat 90.Secara tegas Allah Swt. melarang secara mutlak mengkonsumsi MIRAS haram hukumnya minuman keras (MIRAS).

Minuman keras bukan saja haram dalam meminumnya, tetapi dalam memperjual belikannya, membuatnya, memerasnya, dan menghidangkannya pun hukumnya haram, sesuai dengan Hadis Nabi Muhammad Saw.

${ }^{21}$ Ahmad Husain Ali Salim, Terapi Al-Qur'an untuk Penyakit Fisik dan Psikis Manusia (Jakarta: Asta Buana Sejahtera, 2006), h.253.

${ }_{22}$ Departemen Agama RI, Kesehatan dalam Perpektif Al-Qur'an, (Jakarta: Lajnah Pentashîh $\underline{h}$ Mushhaf Al-Qur'an, 2009), h.287.

${ }^{23}$ Departemen Agama RI \& Kesehatan dalam Perpektif Al-Qur'an, dalam Tafsir Al-Qur'an Tematik, (Jakarta: Lajnah Pentashîh Mushhâf AlQur'an), h.288

${ }^{24}$ Departemen Agama RI, Kesehatan dalam Perpektif Al-Qur'an, dalam Tafir Al-Qur'an Tematik, h.288

${ }^{25}$ M. Quraish Shihab, Tafsir al-Mishbâh, (Jakarta: Mizan, Jilid I), h.471 


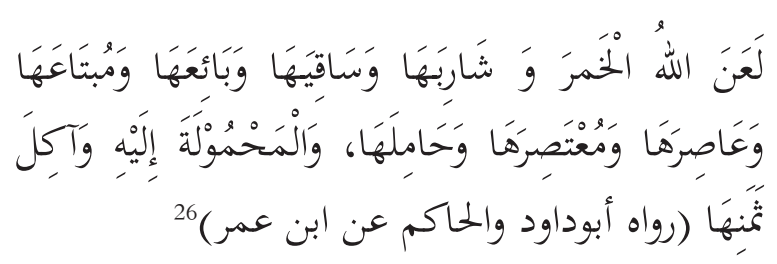

Allah mengutuk khamar, orang yang meminumnya, orang yang menyuguhkannya orang yang menjualnya, orang yang membelinya, orang yang memerasnya, orang yang diperaskan padanya, orang yang membawanya, orang yang dibawakan padanya, dan orang yang memakan harganya." (HR. Abu Dawud dan al-hâkim dari Ibnu Umar).

Melihat dalil-dalil di atas dapat diketahui bahwa hukum NARKOBA tidak terdapat dalam Al-Qur'an dan Hadis. Ini menunjukkan bahwa masa diturunkannya Al-Qur'an dan masa Rasulullah Saw. belum ada, atau belum dikenal istilah NARKOBA. Dengan perjalanan waktu dan perkembangan zaman yang modern ini, para ulama menganalogikan hukum NARKOBA sama dengan hukum minuman keras (khamr). Tidak hanya minuman keras, tetapi apa saja yang menghilangkan akal seperti kecanduan dan lain-lainnya, masuk dalam ranah memabukkan.

Majelis ulama Indonesia (MUI) telah memfatwakan pada tahun 1976, bahwa haram hukumnya penyalahgunaan narkotika dan semacamnya, karena membawa kemudaratan yang mengakibatkan rusaknya mental dan fisik seseorang serta terancamnya keamanan masyarakat bahkan ketahanan Nasional. ${ }^{27}$

NARKOBA dan peredaran minuman keras merupakan masalah serius yang harus diperhatikan oleh Bangsa Indonesia, apalagi sekarang ini Indonesia telah menjadi daerah/lahan yang subur bagi produsen NARKOBA, yang sebelumnya hanya menjadi tempat singgah sementara (transit) ke daerah pasaran NARKOBA. ${ }^{28}$ Selain itu, peredaran minuman keras di beberapa kota besar di Indonesia sudah studium IV/hampir tidak terkendali, MIRAS tersebut dengan mudah diperoleh, bahkan sudah dijual di kios-kios kecil. ${ }^{29}$ Walaupun Indonesia merupakan Negara yang berpenduduk muslim terbesar/mayoritas di dunia yang berjumlah lebih dari 1,6 miliar jiwa, atau sekitar 23,4 persen dari total penduduk dunia, ${ }^{30}$ akan tetapi hal tersebut tidak

\footnotetext{
${ }^{26}$ Jalâluddīn al-Suyûthī, al-Jâmī' al-SHaghìr (Beirut: Dar al-Kutub al-'Ilmiyah, t.th.), Jilid II, h.123.

${ }^{27}$ MUI, Himpunan Fatwa MUI (Jakarta: Penerbit Erlangga, 2011), h. 595

28 Antoro, Jehani Liberus, dkk, Mencegah Terjerumus Narkoba, (Tangerang: Agromedia Pustaka, 2006), h.2

${ }^{29}$ Ekspresi Greater Bandung, Galamedia, "Deden, "Peredaran Miras Tidak Terkendali”, diakses dari http://www.klik-galamedia.com/201409-30/deden-peredaran-miras-tidak-terkendali pada tanggal 16 Oktober 2014

${ }^{30}$ Forum Kompas, "3 Negara Muslim Tersebar Di Dunia”, diakses
}

cukup untuk menghentikan kemungkinan tersebarnya barang-barang haram tersebut di wilayah Indonesia.

Peredaran NARKOBA dan MIRAS merupakan tindak pidana yang masih saja ditemukan di masyarakat, walaupun sudah ada hukum yang melandasi pelanggaran tersebut, yaitu Undang-undang RI NO. 35 Tahun 2009 tentang Narkotika ${ }^{31}$ dan Perpres RI Nomor 74 Tahun 2013 tentang pengadilan dan pengawasan minuman. ${ }^{32}$

NARKOBA memiliki efek jangka pendek dan jangka panjang. Bahaya, atau efek NARKOBA jangka pendek, pertama, Kenikmatan sesaat: menghilangkan stress, perasaan gembira terus dan bebas.Kedua, menghilangkan rasa sakit: NARKOBA bisa menghilangkan rasa sakit, rasa lapar, dan keinginan bercinta.Ketiga, Penurunan fungsi tubuh: sulit bernafas, tekanan darah dan jantung menjadi lemah, pupil mata mengecil.Keempat, mengantuk: jika dosis meningkat, pemakai merasa hangat, berat dan sering mengantuk.Kelima, mabuk: dosis tinggi menyebabkan mabuk dan muntah. Dan keenam, kematian: dosis yang berlebihan dapat menyebabkan kematian. Pernapasan menjadi lemah, suhu tubuh turun dan denyut jantung menjadi tidak teratur. Ketika napas menjadi lemah akan menghentikan fungsi alat-alat tubuh sehingga kematianpun terjadi. ${ }^{33}$

Efek negatif angka panjang Narkotika; pertama, narkotik: impotensi, gangguan haid, kekebalan tubuh menurun, masa bodoh, mengganggu pertumbuhan janin dan kandungan.Kedua, ekstasy: denyut jantung tidak teratur, pendarahan otak, stroke. ${ }^{34}$

Demikian pula halnya minuman keras (MIRAS), atau khamr memiliki dampak negatif terhadap kesehatan dan dapat menyebabkan penyakit-penyakit tertentu, antara lain radang hati kronis dan gagal ginjal, gangguan jantung, merusak daya ingat, dan cedera otak, ${ }^{35}$ bahkan dapat mengakibatkan kematian karena mengkonsumsi MIRAS oplosan yang sudah merenggut 3 nyawa dari pelajar putri. Menurut Bachrul Ilmy, adapun bahaya MIRAS dan NARKOBA

\footnotetext{
dari http:// forum_kompas.com/internasional/290441-3-negara -muslimtersebar-di-dunia.html pada tanggal 1 Oktober 2014

31 "UNDANG-UNDANG REPUBLIK INDONESIA NOMOR 35 TAHUN 2009 TENTANG NARKOTIKA", diakses dari http://epharm.depkes.go.id/ front/pdf/ UU35 2009.pdf pada tanggal 15 Oktober 2014.

32 "PERATURAN PRESIDEN REPUBLIK INDONESIA NOMOR 74 TAHUN 2013 TENTANG PENGENDALIAN DAN PENGAWAAN MINUMAN BERALKOHOL", diakses dari http:// www.kemenag.go.id/file/file/ProdukHukum/qanu1395037364.pdf pada tanggal 15 Oktober 2014

${ }^{33}$ Antoro, Jehane Liberus, dkk, Mencegah Terjerumus NARKOBA, h.8

${ }^{34}$ Antoro ..., Mencegah Terjerumus NARKOBA, 9

35 Timmreck, Thomas, Epidemiologi Suatu Pengantar (Jakarta:
} Penerbit Buku Kedokteran EGC, 2005), h.432 
yaitu: (a) Mengubah kepribadian orang menjadi pemarah, pemurung, pemalas dan masa bodoh. (b) Menurunkan semangat beraktifitas, seperti belajar dan bekerja serta menyiksa diri sendiri.(c) Menjadi gila atau sering hilang kesadaran. (d) Meresahkan masyarakat. (e) Menyebabkan perbuatannya tidak terkendali. (f) Mengganggu keamanan dan ketertiban umum. Dan (g) Mencemarkan nama baik sendiri dan keluarga. ${ }^{36}$

Berdasarkan banyaknya kerugian yang diakibatkan oleh MIRAS dan NARKOBA, pemerintah melarang warganya meminum MIRAS dan penyalahgunaan NARKOBA.

Syariat Islam memerangi dan mengharamkan segala hal yang memabukkan dan segala bentuk NARKOBA dengan berbagai macam jenisnya dan beragam kemasan dan penampilannya. Karena barang-barang itu mengandung bahaya yang nyata bagi kehormatan, kesehatan, akal, reputasi, prestise, dan nama seseorang. Para ulama sepakat atas haramnya mengkonsumsi NARKOBA. Ibnu Taimiyah berkata, "NARKOBA sama halnya dengan zat yang memabukkan diharamkan berdasarkan kesepakatan para ulama. Bahkan setiap zat yang dapat menghilangkan akal, haram untuk dikonsumsi walau tidak memabukkan" (Majmû 'Al-Fatâwâ, 34 :204). ${ }^{37}$

Realitas sosial menunjukkan bahwa banyak sekali kejadian-kejadian kriminal, disebabkan karena pelakunya dalam keadaan mabuk. Perbuatan tersebut dilakukan di luar kesadarannya, karena otak (pikiran) orang yang sedang mabuk khamr, terganggu oleh serangan alkohol pada syaraf pusatnya. Sehingga dapat dikatakan bahwa penyalahgunaan NARKOBA dan konsumsi minuman keras/khamr, merupakan tindakan yang merugikan, baik merugikan bagi orang lain, maupun merugikan bagi diri pengguna tersebut, bahkan membawa korban jiwa sebagaimana terjadi. Begitu pula pada kira-kira 2 tahun yang lalu, akibat mengonsumsi NARKOBA, pengemudi mobil mabuk menabrak 9 orang yang sedang berdiri di trotoar, dan masih banyak lagi kasus-kasus kecelakaan, bahkan pembunuhan yang terjadi akibat mengonsumsi NARKOBA dan mabuk karena MIRAS bahkan banyak yang meninggal akibat mengonsumsi MIRAS oplosan.

Berkenaan dengan bahaya yang terjadi akibat mengkonsumsi MIRAS, maka perluadanya PERDA larangan peredaran MIRAS dari supermarket, mini market dan lain-lain sampai kepada kios-kios kecil.

\footnotetext{
${ }^{36}$ Bachrul Ilmy, Pendidikan Agama Islam (Bandung: Grafindo Media Pratama, 2008), h.110

37 Narkoba dalam Pandangan Islam" diakses pada tanggal 10 Oktober dari http://muslim.or.id/fiqh-dan-muamalah/narkoba-dalampandangan-islam.html
}

Seperti yang dilakukan oleh PEMDA DKI dan Mentri Perdagangan sekarang ini, di samping dakwah amr márüf nabi munkar dari para Ulama dan Dâi. Begitu pula halnya NARKOBA, bukan hanya pelarangan mengonsumsinya, akan tetapi yang paling penting adalah pemilik pabrik/ produsen, para bandar, penjual dan pengedarnya, harus diberi hukuman yang setimpal, yang berat dan ringannya tergantung pada tingkatan pelanggaran dan kejahatan yang dilakukan, bahkan bila perlu dapat dihukum mati seperti yang dilakukan oleh pemeritah Indonesia pada tanggal 18 Januari 2015 mengeksekusi 6 orang terpidana mati kasus NARKOBA, di Lapas Nusa Kambangan dan Boyolali, dimana Presiden RI menolak permintaan grasinya, agar menjadi pelajaran bagi yang lain supaya tidak melakukan perbuatan seperti itu. Keputusan pemerintah terhadap pidana mati tersebut, sesuai dengan prinsip syariah dan fikih, untuk mencegah mafsadah dan mewujudkan kemashlahatan.

Sehubungan dengan hukuman mati, Majelis Ulama Indonesia dalam MUNASnya yang ke VII tahun 2005 telah menetapkan fatwa dalam tindak pidana tertentu, mengatakan bahwa Islam mengakui eksistensi hukuman mati dan memberlakukannya dalam jarimah (tindak pidana) hudūd, qishâsh dan ta’zìr. Negara boleh melaksanakan hukuman mati bagi pelaku kejahatan pidana tertentu. ${ }^{38}$ Hukuman mati dalam kasus NARKOBA adalah termasuk hukuman $t a^{\prime} z i \bar{r}$. ${ }^{39}$

\section{Penutup}

Dari uraian di atas dapat disimpulkan bahwa ajaran Islam yang berpegang kepada Al-Qur'an dan al-Hadis sebagai sumber syariah dan fikih tetap relevan sepanjang zaman, dan akan selalu seiring dengan perkembangan masyarakat dan kemajuan IPTEK.

$$
\text { الإسلام صالح لكل زمان ومكان }
$$

Islam sesuai dan relevan dengan setiap kondisi, keadaan, waktu dan tempat.[]

\section{Pustaka Acuan}

Abdullah Yusuf Ali. Qur'an Terjemahan dan Tafirinya, Terjemahan Ali Audah. Jakarta: Pustaka Firdaus, 1993. Abdul Wahab Abd. Muhaimin. Hukum Islam dan Kedudukan Perempuan dalam Perkawinan dan Perceraian. Jakarta: Gaung Persada Press, 2013.

\footnotetext{
${ }^{38}$ MUI, Himpunan Fatwa MUI, h.502

39 Hukuman Tázir adalah hukuman yang belum ada ditentukan dalam Al-Qur'an dan Hadis, tetapi ketentuan hukumnya, diserahkan kepada ijtihad dan kebijaksanaan para hakim berat dan ringannya, untuk mencegah kemudaratan dan mendatangkan maslahat serta mewujudkan
} keadilan 
Abdul Wahhab Khallâf.Ilmu ushül Fikih. Kuwayt: Dar al-Qalam, t,th

Adrian Sutedi.Tindak Pidana Pencucian Uang. Bandung: Citra Aditya Bakti, 2008.

Ahmad Husain Ali Salim. Terapi Al-Qur'an untuk Penyakit Fisik dan Psikis Manusia. Jakarta: Asta Buana Sejahtera, 2006

Ali Muhammad al-Jurjânî.al-Tárîfât.Mesir: Mushtafâ al-

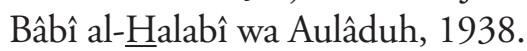

Antoro, Jehani Liberus, dkk. Mencegah Terjerumus Narkoba. Tangerang : Agromedia Pustaka, 2006.

Bachrul Ilmy.Pendidikan Agama Islam.Bandung: Grafindo Media Pratama, 2008.

Depag RI. Al-Quian dan Tafsirnya (edisi yang disempurnakan). Jakarta: Balitbang Agama, 1425 $\mathrm{H} / 2004 \mathrm{M}$.

, Kesehatan dalam Perpektif Al-Qur'an. Dalam Tafsir Al-Qur'an Tematik. Jakarta: Lajnah Pentashhîh $\underline{\underline{h}}$ Mushhâf Al-Qur'an, 2009

Ekspresi Greater Bandung, Galamedia. "Deden, "Peredaran Miras Tidak Terkendali". diakses dari http://www.klik-galamedia.com/2014-09-30/dedenperedaran-miras-tidak-terkendali pada tanggal 16 Oktober 2014.

Forum Kompas. "3 Negara Muslim Terbesar Di Dunia”. diakses dari http://forum_kompas.com/ internasional/290441-3-negara -muslim-tersebar-didunia.html pada tanggal 1 Oktober 2014.

Ibnu Ăsyūr. Anwâr al-Tanzîl wa atharu al-Tảwiîl. t.t.: Maktabah Shâmilah, t.th.

Ibnu Manzhūr.Lisân al-'Arab.t.t.:Dar al-Ma'arif, t.th.

Jaes D. Harmon Jr. "Money Laoundring Legislation: Hearing of the Senat Comm". On The Judiciary, 99th Cong, Vol. 84, 1983.

Jalâluddīn al-Suyūthī.al-Jâmī al-Shaghìr. Beirut: Dar alKutub al-'Ilmiyah. 1415 H / 1995 M.
Kementrian Agama RI. "Al-Qur'an dan Isu-isu Kontemporer I". dalam Tafsir Al-Qur'an Tematik. Jakarta: Lajnah Pentashhîh Mushhâf Al-Qur'an, 2012. Pembangunan Ekonomi Umat Islam dalam Tafsir Al-Qur'an Tematik. Jakarta: Lajnah Pentashhîh Mushhâf Al-Qur'an, 2012.

Majmâ‘ al-Lughah al-'Arabiyah. al-Mu'jam al-WasîTh. Mesir: Dar al-Ma'ârif 1392 H/1972 M.

MUI.Himpunan Fatwa MUI. Jakarta: Penerbit Erlangga, 2011.

M. Quraish Shihab. Tafsir al-Mishbâhb. Jakarta: Mizan, 2000.

Mannầ Khalîl al-Qaththân, al-Tashrì̀ wa al-fiqh fì alIslâm: Târîkhan wa Manhajan. t.t.: Maktabah t.t.: Maktabah Wahbah, 1976.

Muhammad Abu Zahrah.Ushūl al-Figh. t.t.: Dar al-Fikr al-Arabî, t.th.

Muhammad al-Thahanâwî, Kashshâf Istilâhât al-Funūn, t.t.: al-Isti'anah, $1317 \mathrm{H}$.

"PERATURAN PRESIDEN REPUBLIK INDONESIA NOMOR 74 TAHUN 2013 TENTANG PENGENDALIAN DAN PENGASWAAN MINUMAN BERALKOHOL". diakses dari http://www.kemenag.go.id/file/file/ProdukHukum/ qanu1395037364.pdf pada tanggal 15 Oktober 2014.

Al-Qurthubī, al-Jâmi' li Abhkâm Al-Qur'an. t.t. : t. p., $1372 \mathrm{H} / 1952 \mathrm{M}$

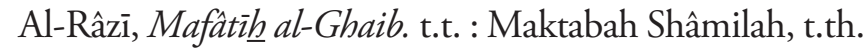

Timmreck, Thomas. Epidemiologi Suatu Pengantar, Jakarta: Penerbit Buku Kedokteran EGC, 2005.

Al-Zamakhsharî.al-Kashshâf. t.t. : Maktabah Shâmilah, t.th.

"UNDANG-UNDANG REPUBLIK INDONESIA NOMOR 35 TAHUN 2009 TENTANG NARKOTIKA". diakses dari http://e-pharm. depkes. go.id/ front/ pdf/ UU352009.pdf pada tanggal 15 Oktober 2014. 